UDK 821.111(73)-311.6.09Mailer N.

\title{
NORMAN MAILER - THE MOST INFLUENTIAL CRITIC OF CONTEMPORARY REALITY IN THE SECOND HALF OF THE TWENTIETH CENTURY
}

\author{
Jasna Potočnik Topler
}

\begin{abstract}
Norman Mailer, one of the most influential authors of the second half of the twentieth century, faithfully followed his principle that a writer should also be a critic of contemporary reality. Therefore, most of his works portray the reality of the United States of America and the complexities of the contemporary American scene. Mailer described the spirit of his time - from the terror of war and numerous dynamic social and political processes to the 1969 moon landing. Conflicts were often in the centre of his writing, as was the relationship between an individual and the society; he speaks of political power and the dangerous power of capital, while pointing to the threat of totalitarianism in America. Mailer spent his entire career writing about violence, power, perverted sexuality, the phenomenon of Hitler, terrorism, religion and corruption. He continually pointed out that individuals were in constant danger of losing freedom and dignity.
\end{abstract}

Keywords: American novel, political power, Norman Mailer, literary journalism

Norman Kingsley Mailer, a Pulitzer Prize-winning novelist and journalist, and one of the most influential authors of the second half of the twentieth century, faithfully followed his principle that a writer should also be a critic of contemporary reality. One of his biographers Mary V. Dearborn wrote, »In the case of Norman Mailer, the man and his life are of equal, often competing stature with his work, and it is for his life as well as his work that he will be remembered « (Dearborn 8). He did not hide who he was or how he felt or what he thought. Columnist Jimmy Breslin said that he was »one of the half-dozen original thinkers in this century « and that his ideas would last (Dearborn 3). His works are, no doubt about that, very popular and always among best-sellers, including his last novel The Castle in the Forest (2007) (nmwcolony.org). 2013 marks the 90th anniversary of Mailer's birth.

In eighty-four years Mailer wrote more than forty books, married six times, had nine children, ten grandchildren, he experienced many different roles and was, among other things, actively engaged in politics. In 1969, he was a candidate in the Democratic primary race for mayor of New York City, sharing a ticket with the equally outrageous journalist Jimmy Breslin, running for president of city council. Their campaign slogan 
was: »The other guys are the joke!« Mailer received only 41,000 votes (Breslin got 75,000 but still came in fourth of five candidates). Fortunately, Mailer applied his drive and energy with more success in service of the literary community and continued writing. It is not emphasized enough that Mailer was instrumental in fortifying literary life for writers of all genres. He was a co-founder of The Village Voice, which in its early years »had a greater impact on the non-fiction/journalistic world than any other single publication, with the possible exception of Esquire and The New Yorker« (Gutking 6). In his later years, Mailer was, among other things, a president of the PEN American Center and - according to his contemporary Gay Talese, a member of the organization at the time - used his prestige and devoted his time to putting the organization on the map, nationally and internationally (ibid.).

Norman Mailer died on November 10th 2007, but his legacy contiues at Norman Mailer Society and Norman Mailer Center. The Norman Mailer Society is a nonprofit organization, founded in 2003 to celebrate Norman Mailer. It has approximately 300 members and meets annually for three days for panels, papers, films and informal discussion about the life, work and reputation of the late chronicler of the American contemporary reality. The organization also publishes The Mailer Review, which is cosponsored by the University of South Florida (normanmailersociety.org). The Norman Mailer Center and Writers Colony is also a non-profit organization for educational purposes, and has been established to honour Norman Mailer's work and lifelong interest in and commitment to writers and writing programmes. The Mailer house in Provincetown serves as the Center's and Colony's headquarters for students, fellows, writers and scholars from all over the world (nmcenter.org). Official biographer of Norman Mailer is J.Michael Lennon, Emeritus Professor of English at Wilkes University, Texas. He maintained a close personal relationship with Mailer for more than thirty years. Lennon has published widely on Mailer, including (with Donna Pedro Lennon), Norman Mailer: Works and Day (2000), and edited several of Mailer's works, including Pieces and Pontifications (1982), Conversations with Norman Mailer (1988), The Spooky Art: Some Thoughts on Writing (2005), and On God: An Uncommon Conversation (2007). Lennon's collection of Mailer correspondence consists of eight folders of outgoing and incoming letters with Mailer. Carbons and photocopies of Lennon's letters to Mailer date from 1971 to 1993 and include Lennon's first letter to Mailer regarding Mailer's appearance with Gore Vidal and Janet Flanner on »The Dick Cavett Show, « December 2, 1971. Original typed and handwritten letters from Mailer to Lennon date from 1972 to 1993 and contain Mailer's comments on his literary and personal activities. Estimations show that there are about 50,000 letters (research.hrc.utexas.edu). J. Michael Lennon comments that »perhaps no career in American literature has been as brilliant, varied, controversial, public, productive, lengthy and misunderstood « as Mailer's and believes that Mailer matters for three main reasons:

1. Mailer was the key innovator in the new wave of participatory journalism that took place in the late 1950 s and early $1960 \mathrm{~s}$. He argued that there were no immutable boundaries, no lines drawn in heaven, between the genres, and demonstrated this by drilling holes through all the watertight compartments dividing them. 
2. Mailer was the most important public intellectual in the American literary world for over 30 years, and along with other figures such as William Buckley, Saul Bellow, Gore Vidal and Susan Sontag, helped establish the creative writer as important a commentator as politicians, pundits and professors. Mailer presented his ideas and commentary on modern politics and culture in every major media venue, save the Internet, and he even dabbled there in his final years. No American writer going back to Mark Twain mastered the modes of communicating with a variety of audiences for as long or as well as Mailer. He wrote for every sort of magazine and journal, underground and aboveground-Partisan Review, Parade, Esquire, Playboy, Way Out, Fuck You: A Magazine of the Arts, Dissent, Life, Look, Village Voice, Nugget, the NYRB and the New Yorker - over 100 different periodicals. He appeared on every major talk show, and many obscure ones.

3. Mailer was the most important chronicler of and commentator on the major events and figures of American life during the last half of the twentieth century. He had daring ideas and insights on the great events and phenomena of the period: the Depression and World War II, McCarthyism and the Hollywood blacklist, the Cold War, Black Power, the sexual revolution, Vietnam and civil disobedience, the Women's Liberation Movement, technology and the space program, prize fights and political conventions (he covered six), and some of the most loved and hated persons of the 20th century: Muhammad Ali and Marilyn Monroe, Hemingway, Castro, Nixon, Gary Gilmore, Lee Harvey Oswald, Madonna, Jackie Kennedy, Picasso and Henry Miller, and at the end of his life, Adolph Hitler (Lennon, normanmailersociety.org).

Most of Norman Mailer's works portray the reality of the United States of America and the complexities of the contemporary American scene. Mailer described the spirit of his time - from the terror of war and numerous dynamic social and political processes to the 1969 moon landing. Conflicts were often in the centre of his writing, as was the relationship between an individual and the society; he speaks of political power and the dangerous power of capital, while pointing to the threat of totalitarianism in America. Mailer spent his entire career writing about violence, power, perverted sexuality, the phenomenon of Hitler, terrorism, religion and corruption. He continually pointed out that individuals were in constant danger of losing freedom and dignity.

The article reveals the areas of social and political contemporary life that were most often critically referred to by Mailer. My analysis concentrates on his fictional works The Naked and the Dead (1948), An American Dream (1965) and Why Are We in Vietnam? (1967) as well as on his non-fiction works The Armies of the Night (1968), Miami and the Siege of Chicago (1968), Of a Fire on the Moon (1970), The Executioner's Song (1979) and Why Are We at War? (2003). Further on, I discuss how Mailer's work influenced thought and action in America and conclude by elaborating on Mailer's influence on Slovenian literary creation. 
Mailer writes about how fighting for freedom and democracy can run afoul of laudable intentions. His first book The Naked and the Dead, is as much a remarkable novel about the Second World War as it is a pessimistic account of the future. The New York Times wrote that this was »the most impressive novel about the Second World War /.../ Mr. Mailer is as certain to become famous as any fledgling novelist can be « (Mils 100). Mailer was a great and obsessed stylist:

The division task force had been warned that the forests of Anopopei were formidable, but being told this did not make it easier. Through the densest portions, a man would lose an hour in moving a few hundred feet. In the heart of the forests great trees grew almost a hundred yeards high, their lowest limbs sprouting out two hundred feet from the ground. Beneath them, filling the space, grew other trees whose shrubbery hid the giant ones from view. And in the little room left, a choked assortment of vines and ferns, wild banana trees, stunted palms, flowers, brush and shrubs squeezed against each other, raised their burdened leaves to the doubtful light that filtered through, sucking for air and food like snakes at the bottom of a pit. In the deep jungle it was always as dark as the sky before a summer thunderstorm, and no air ever stirred. Everything was dam and rife and hot as though the jungle were an immense collection of oily rags growing hotter and hotter under the dark stifling vaults of a huge warehouse. Heat licked at everything, and the foliage, responding, grew to prodigious sizes. In the depths, in the heat and the moisture, it was never silent. The birds cawed, the small animals and occasional snakes rustled and squealed, and beneath it all was a hush, almost palpable, in which could be heard the rapt absorbed sounds of vegetation growing. (Mailer, Naked 37)

Also Morris Dickstein says that »Mailer had a genius for description, for evoking atmosphere, « (2007: 123).

In The Naked and the Dead Mailer notices that the army and society alike are crippled by inhumanity, violence and brutality, dehumanisation, materialism and corruption, and concludes that this is devastating for the United States of America. His subjects are inequality, terrorism, religion, the question of Jewishness and the pathology of power. He is critical towards people in power that tolerate, enable and even encourage violence. Later, Mailer emphasises that big corporations have far too much influence on American life. According to him, the American society is threatened by totalitarianism. Gabriel Miller says that this is »ultimately a political novel « (68), and continues: »In this first novel Mailer equates the army with society and thereby explores the fragmented nature of that society, which has militated against social development, revolutionary or otherwise « (ibid.). As far as the style of the novel is concerned, Miller (68) clearly states: »The novel exhibits a hodgepodge of styles and influences: the works of James Farrell, John Steinbeck, and John Dos Passos inform its structure and form. « And Mailer himself commented on the novel as follows:

I didn't have much literary sophistication while writing The Naked and the Dead. I admired Dos Passos immensely and wanted to write a book that 
would be like one of his. My novel was frankly derivative, directly derivative ... I had four books on my desk all the time I was writing: Anna Karenina, Of Time and the River, U. S. A., and Studs Lonigan ....The atmosphere of The Naked and the Dead, the overspirit, is Tolstoyan; the rococo comes out of Dos Passos; the fundamental, slogging style from Farrell, and the occasional overrich descriptions from Wolfe. (Manso 101)

In An American Dream, the salient themes are religion, church, God, the Devil, life after death, and violence. The protagonist Stephen Richards Rojack from New York is a murderer:

I struck her open-handed across the face. I had meant - some last calm intention of my mind had meant - to make it no more than a slap, but my body was speaking faster than my brain, and the blow caught her on the side of the ear and knocked her half out of bed. She was up like a bull and like a bull she charged. Her head struck me in the stomach (setting off a flash in that forest of nerves) and then she drove one powerful knee at my groin (she fought like a prep-school bully) and missing that, she reached with both hands, tried to find my root and mangle me. That blew it out. I struck her a blow on the back of the neck, a dead cold chop which dropped her to a knee, and then hooked an arm about her head and put a pressure on her throat. She was strong, I had always known she was strong, but now her strength was huge. For a moment I did not know if I could hold her down, she had almost the strength to force herself up to her feet and lift me in the air, which in that position is exceptional strength even for a wrestler. For ten or twenty seconds she strained in balance, and then her strength began to pass, it passed over to me, and I felt my arm tightening about her neck. My eyes were closed. I had the mental image I was pushing with my shoulder against an enormous door which would give inch by inch to the effort. (Mailer, American 35)

The novel had definitely divided critics. Andrew Gordon (1980: 14) said:

Mailer wanted to return America to an awareness of its suppressed desires, to tap into the buried dream life of the nation ... Thus he wrote a novel, An American Dream (1965), a blend of pop fiction thriller and heroic myth. An American Dream is a phantasmagoria of the unconscious in which rationality is thrown out the window (along with the hero's wife). In this novel, what Freud called 'the primary process,' the workings of the id, rules: the dense imagery and symbols seem formed through the psychic processes of condensation and displacement, and the plot is deliberately riddled with bizarre coincidences and irrational and magical events - all the logic of a dream.

And another critic Donald L. Kaufmann pointed out: »An American Dream, with its tantalizing cluster of images, metaphors and near-symbols, is a novel of suggestion, not explanation, a trap for any critic or reader on a symbol hunt « (2007: 201). 
In An American Dream »much is implied « and »little substantiated « (Kaufmann 201 ), and that is why outer reality could also be interpreted as a metaphor for the United States of America. Kaufmann (194-195) continues:

Mailer's An American Dream does not focus on the gross Dream of an America crisscrossed with telephone wires and television antennas, whose fad of the sixties is the conquest of the moon. Rather Mailer's novel, based on total cultural delicacies, is a dramatic critique on those nuances underlining the ambigous values in contemporary America, on those individual roots of American aspirations and ideals.

Mailer believes that American society is too dependent on religion and church, and that that is the reason why people avoid important subjects: »Since the Church refuses to admit the possible victory of Satan, man believes that God is all-powerful. So man also assumes God is prepared to forgive every last little betrayal. Which may not be the case. God might be having a very bad war with troops defecting everywhere. Who knows? Hell by now might be no worse than Las Vegas or Versailles« (American 221).

Church is also strongly criticised by Mailer because it represents the interests of the wealthy elites. Comparing Las Vegas and Versailles, he points towards the corrupted world of the rich, who are lacking in values. Mailer is strongly engaged in criticising the American type of capitalism and consumerism. He raises several other important questions, among them the problem of abortion and the responsibility for the unborn child. And of course he is very critical of irresponsible reporting done by the media. Implicitly, he even states that American society is not only totalitarian but also incestouous. »In An American Dream, Mailer took a cliché (as indicated by his title) and made of it an allegorical indictment of American society « (Leeds 2002: 84).

Despite Mailer's disbelief in the American myth of a promised land, he maintains a firm faith in the United States of America. In The Armies of the Night, he implies that hope lies in the young generations:

At any rate, we have an army of at least 35.000 amateur soldiers consisting of doctors, dentists, faculty, veterans groups, housewives, accountants, trade unionists, Communists, Socialists, pacifists, Trotskyists, anarchists, artists, and entertainers, no, even historians may have a joke - there was no more than a smattering and a sprinkling of such professionals at the Pentagon. Present in the majority were college students from all over the East, and high school students and hippies and Diggers and bikers. (Mailer, Armies 274)

As a moral example, he presents the courage of the protesters in the 1967 march against the Pentagon - the symbol of power. He questions the relationship between history and fiction and emphasizes the irresponsible reporting of media, who sell fiction as facts, as a major problem. He sees America as a very divided society - there is a discrepancy between the left and the right, the rich and the poor, the young and the old, the whites and the blacks. In the book subtitled History as a Novel/The Novel as History, for example, he not only explained his opposition to the Vietnam War but laid bare his feelings and his political commitment. He skillfully enmeshed political rhetoric into storytelling. In 1968 Kazin wrote: »I believe that it is a work of personal and political 
reportage that brings to the inner and developing crisis of the United States at this moment admirable sensibilities, candid intelligence, the most moving concern for America itself. Mailer's intuition in this book is that the times demand a new form. He has found it (nytimes.com). And continued:

The book cracks open the hard nut of American authority at the center, the uncertainty of our power - and, above all, the bad conscience that now afflicts so many Americans. Armies of the Night is a peculiarly appropriate and timely contribution to this moment of the national dramas, and among other things, it shows Mailer relieved of his vexing dualities, able to bring all his interests, concerns and actually quite traditional loyalties to equal focus. The form of this diary-essay-tract-sermon grew out of the many simultaneous happenings in Washington that weekend, out of the self-confidence which for writers is style, out of his fascination with power in American and his fear of it, out of his American self-dramatizing and his honest fear for his country. (nytimes.com)

In The Armies of the Night Mailer exercised »participatory journalism«:

On a day somewhat early in September, the year of the first March on the Pentagon, 1967, the phone rang one morning and Norman Mailer, operating on his own principle of war games and random play, picked it up. That was not characteristic of Mailer. Like most people whose nerves are sufficiently sensitive to keep them well-covered with flesh, he detested the telephone. Taken in excess, it drove some psychic equivalent of static into the privacies of the brain; so he kept himself amply defended. He had an answer service, a secretary, and occasional members of his family to pick up the receiver for him - he discouraged his own participation on the phone - sometimes he would not even speak to old friends. Touched by faint intimations of remorse, he would call them back later. He had the idea - it was undeniably oversimple - that if you spent too much time on the phone in the evening, you destroyed some kind of creativity for the dawn. (Mailer, Armies 14-15)

In The Spooky Art Mailer wrote that the style of The Armies of the Night was the influence of Henry Adams:

The influence of Henry Adams on The Armies of the Night is peculiar. I had never read much Adams. In my Freshman year at Harvard, we were assigned one long chapter of The Education of Henry Adams, and I remember thinking at the time what an odd thing to write about yourself in the third person. Who is this fellow, Henry Adams, talking about himself as Henry Adams? I remember being annoyed in that mildly irritable way Freshmen have of passing over extraordinary works of literature. To my conscious recollection, I hardly ever thought about him again. Yet, start reading The Armies of the Night, and immediately you say - even I said - »My God, this is pure Henry Adams. «It's as if I were the great-grandson. Contemplate, therefore, how peculiar is influence: Adams must have remained 
in my mind as a possibility, the way a painter might look at a particular Picasso or Cezanne and say to himself, »That's the way to do it. « Yet the influence might not pop forth for twenty or thirty years. When it does, the painter could say, »Oh yes, that was a Picasso I saw at MoMA twenty-five years ago, and I've always wanted to try such a palette, and now I have.« In effect, that's what happened with Henry Adams. (Mailer, Spooky 99)

Mailer was talking about himself in the third person, which he commented:

While it seemed interesting up to a point to speak of a protagonist named Norman Mailer, it was, on the other hand, damned odd. I was halfway into the book before I got used to it. It is even a dislocating way to regard oneself. Yet by the time I was done, I missed this character of Norman Mailer so much that I brought him back for book after book. It never worked as well again. The commitment has to be there. In The Armies of the Night, I was a true protagonist of the best sort - half-heroic, three-quarters comic. (Mailer, Spooky 127)

Also Why Are We in Vietnam? portrays the violence of American society. In accordance with his left-conservatism, Mailer strongly opposes the war in Vietnam. He believes that America's involvement in Vietnam is unjust and perverted and that fighting wars in foreign countries for the hidden reasons of wealth and corruption is immoral. Later Mailer commented on the novel:

Why Are We In Vietnam? is the only novel I ever finished under the mistaken belief I was writing another. / . . / I imagined a group of seven or eight bikers, hippies and studs plus a girl or two, living in the scrub thickets that sat in some of the valleys between the dunes. Only six feet high, those thickets were nonetheless forests, and if you could find a path through the thorns and cat briars, nobody could track you, not in a hurry. So I peopled the thickets with characters: My characters were as wild as anyone who ever came to Provincetown. /.../ I began the book in the spring of " 66 . It attracted me too much not to begin. Yet because I could not thrust Provincetown into such literary horrors without preparation, I thought I would start with a chapter about hunting bear in Alaska. A prelude. I would have two tough rich boys, each as separated from social convention as any two rich boys could be - Texans I would make them, out of reserve memories of Texans I had served with in the 112th Cavalry out of San Antonio. The boys would still be young, still mean rather than uncontrollably murderous - the hunting might serve as a bridge to get them ready for more. They would come back from the Alaskan hunting trip ready to travel; Provincetown would eventually receive them. (Mailer, Spooky 233-234)

Mailer also reminds us, in Miami and the Siege of Chicago, that freedom should not be taken for granted; rather, it should be fought for every day: »Freedom does not work unless we work at it, « he said, »and that I believe to be part of the reason for the spirit and determination of so many of the young people« (Mailer 200). He elaborates 
on many other topics and problems, including youth, finance, and environmental pollution. The book, however, is very important because it is an excellent example of how politics can abuse rhetoric. Between the lines, the author once again shows that insidious American political decisions taken mean that American politics has characteristics of totalitarianism:

Politics is property; property relations are law-abiding. Even seizure of property can be accomplished legally. So the history of a convention must concern itself with law-abiding citizens; conversely, a study of law-defying citizens who protested the deliberations of this convention in the street ought to find them propertyless, therefore not in politics. In fact, it does not. Not quite. There were two groups to the army of young people who assembled in Chicago; one could divide them conveniently as socialists and existentialists. The socialists, you can be certain, believed in every variety of social and revolutionary idea but membership in the Socilist Party, which of course, being young people, they detested; for the most part they were students of the New Left who belonged to SDS, the Resistance (a movement of confirmed draft resisters) and a dozen or more peace organizations. While their holdings were almost entirely in moral property, it would take a strong country mind to claim that socialists have no property relations in their own politics, since indeed there are ideologies among these sissies, Governor Maddox, which have passed down like a family trust through the generations, and the war for control of a radical committee will often revolve around the established seat of the Chairman. (Mailer, Miami 128)

Mailer is often very pessimistic about the future of the United States of America. Of a Fire on the Moon is a book-length example of this pessimism. He realises that the driving force of everything, including the space flights, is corporate capitalism. The landing of Apollo on the moon opened the way to space imperialism. Consequently, the world will never be the same. Mailer contemplates the future of the planet and is very worried because technology has come to prevail over nature:

So the century feels a profound anxiety. That anxiety lives like the respirations of a clam in the clammy handshakes of all too many technologists and technicians. They know their work is either sufficiently liberating to free man from the dread of his superstition-ridden past, or their work smashes real and valuable taboos, and so becomes sacrilegious acts upon a real religious fundament. Could this not yet destroy the earth as it has already disrupted every natural economy of nature? That is the primary source of the great anxiety of the technologist as he stands before the idea that a machine may have a psychology. (Mailer, Fire 152)

Mailer believes that with progress there will be less nature and consequently less future. Self destruction is often on Mailer's mind.

The writer's left-conservatism is also seen in his criticism of complex and divided American society in The Executioner's Song. Mailer explained his decision to write a novel about Gilmore in The Spooky Art: 
I may not be a good intellectual, but my avocation is, nonetheless, to create intellections. I put them on like adhesive plasters. In the case of Gary Gilmore, however, I had to pull them off. As I explored deeper into what Gilmore's nature might be, I decided that every concept I had about him was inadequate. So I wanted the reader of The Executioner's Song to confront the true complexity of one human. That state of perception will always arise by studying any person close enough. That he was a murderer made my task simpler, because we are all fascinated by killers. But any person studied in depth will prove fascinating. It is certainly the yeast in any good marriage. Take any soul alive, and he or she can prove exceptional provided you get to know him or her well enough. Of course, if we are dealing with a sad case, the exceptional element is more likely to be found in the canyons of their horrendous bad luck or in the contortions of an ongoing cowardice. Or both. Bad luck feeds fear; the obverse may be equally true. (Mailer, Spooky 152-153)

In the novel, the author stresses the lack of values, along with violence, the irresponsibility of the media and of course the dilemma of the death sentence that is in opposition to the value of life.

Why Are We At War? is a book that deals with topics that have accompanied Mailer since his first book in 1948. Once again, he clearly articulates his opinion on patriotism, terrorism, capitalism, totalitarianism and American foreign policy:

Probably half of America has an unspoken desire to go to war. It satisfies our mythology. America, goes our logic, is the only force for good that can rectify the bad. George W. Bush is shrewd enough to work that equation out all by himself. He may even sense better than anyone how a war with Iraq will satisfy our addiction to living with adventure on TV. If this is facetious, so be it - the country is becoming more loutish every year. So, yes, war is also mighty TV entertainment. (Mailer, War 54)

$\mathrm{He}$ is further on worried about curtailing of liberties:

If we have a depression or fall into desperate economic times, I don't know what's going to hold the country together. There's just too much anger here, too much ruptured vanity, too much shock, too much identity crisis. And, worst of all, too much patriotism. Patriotism in a country that's failing has a logical tendency to turn fascistic, just as too much sentimentality will corrupt compassion. Fascism in America is not going to come with a political party. Nor with black shirts or brown shirts. But there will be a curtailing of liberties. Homeland Security has put the machinery in place. The people who are running the county, in my opinion, simply do not have the character or wisdom to fight the concept of freedom if we suffer horrors; no, not if we suffer dirty bombs, terrorist attacks on a huge scale, virulent diseases. The notion that you're going to have your freedom saved by people who work for security agencies is curious at best. They're on a one-way street. Anything bad of that sort is very bad for them. So they're going to 
do their utmost to restrict the freedom of people during critical situations. In the final analysis, democracy is inimical to security. Americans have to be willing to say at a certain point that we're ready to take some terrorist hits without panicking, that freedom is more important to us than security. (Mailer, War 105-106)

In Why Are We at War? Mailer points out that the fact that a country was once a democracy does not guarantee it will be a democracy forever.

Despite topic themes and his extraordinary writing style, Norman Mailer was often overlooked in Slovenian literary environment. The Slovenian media wrote about him when his new novels were released, and his personality was of great interest to them, but reflexive reviews were rare - with the exception of the national Radio Slovenia. Mailer is, however, an interesting subject for theses and dissertations among students at Slovenian universities.

Ljubljana

\section{WORKS CITED}

Dearborn, Mary V. Mailer: A Biography. Boston, New York: Houghton Mifflin Company, 1999.

Dickstein, Morris. »How Mailer bacame 'Mailer': the writer as private and public character«. The Mailer Review: Inaugural Issue (2007): 118 - 131.

Glenday, K. Michael. »The Hot Breath of the Future: The Naked and the Dead.«Bloom's Modern Critical Views: Norman Mailer (2003): 197 - 210.

Gordon, Andrew. An American Dreamer. Toronto: Associated University Press, 1980.

Gutkind, Lee. »A tribute to Norman Mailer on the 30th anniversary of the Executioner's Song's Pulitzer Prize.« Creative Nonfiction (2010): 6.

Kaufmann, Donald L. »An American Dream: The Singular Nightmare.«The Mailer Review: Inaugural Issue (2007): 194 - 205.

Leeds, Barry H. The Enduring Vision of Norman Mailer. Bainbridge Island: Pleasure Boat Studio, 2002.

Mailer, Norman. An American Dream. New York: Dell Publishing Co., Inc., 1969. . The Armies of the Night: History as a Novel, the Novel as History. New York: The New American Library, 1968. . The Executioner's Song. Boston, Toronto: Little, Brown and Company, 1979. . A Fire on the Moon. London: Pan Books Ltd., 1970.

. Miami and the Siege of Chicago: An informal history of the American political conventions of 1968. Harmondsworth, Victoria: Penguin Books Ltd., 1969. . The Naked and the Dead. New York: Holt, Rinehart and Winston, Inc., 1976. . The Spooky Art: Some Thoughts on Writing. New York: Random House, 2003.

. Why Are We in Vietnam?: A Novel. New York: G. P. Putnam's Sons, 1967.

Manso, Peter (1985): Mailer: His Life and Times. New York: Penguin Books. 
Miller, Gabriel. »A Small Trumpet of Defiance: Politics and the Buried Life in Norman Mailer's Early Fiction.«Bloom's Modern Critical Views: Norman Mailer (2003): $67-80$.

Potočnik Topler, Jasna. »Družbenokritična ost v delih Normana Mailerja« (doktorska disertacija). Ljubljana: FF, 2012.

Online sources:

Kazin, Alfred. “The Trouble He’s Seen.” New York Times, 5. 5. 1968. (nytimes.com), 24. 11. 2011.

Lennon, J. Michael. 'Why Mailer Matters.' (normanmailersociety.org/2011/12/29/ participatory-journalism-of-norman-mailer), 30. 12. 2011.

Lennon, J. Michael. »A Preliminary Inventory of His Correspondence with Norman Mailer at the Harry Ransom Humanities Research Center.« (research.hrc.utexas.edu)

Siegel, Lee. "Maestro if the Ego." New York Times. 21. 1. 2007. (query.nytimes.com), 28. 4. 2007.

The Norman Mailer Society (normanmailersociety.org)

The Norman Mailer Center (nmcenter.org) 